\title{
Desbordar como contraconduta
}

\author{
Overflow embroidery as counter-conduct \\ Desbordamiento como contraconducta
}

Mariana Guimarães

Instituição: Universidade Federal do Rio de Janeiro

E-mail: marianasguimaraes@hotmail.com

ORCID: https://orcid.org/0000-0003-4009-3451

Gabriela Serfaty

Instituição: Pontificia Universidade Catolica - Núcleo de Subjetividades

E-mail: gabiserfaty82@gmail.com

ORCID: https://orcid.org/0000-0002-3995-7593

RESUMO:

O presente trabalho apresenta algumas reflexões a partir de encontros e diálogos desenvolvidos na oficina Desbordar, desenvolvida com usuários do serviço de saúde mental no Hospital-dia Casa Verde, localizado na Zona Sul do Rio de Janeiro. O texto é construído a partir de uma polifonia ecoada das vozes dos pacientes e das pesquisas desenvolvidas pelas autoras, frente a percepções sobre a linguagem, e a partir também do método proposto, em que as amarras da linguagem, das imagens e das palavras são liberadas de uma homogeneização prisional, de um modelo único e limitante.

Palavras-chave: Bordado Contemporâneo. Arte Educação. Clínica.

\section{ABSTRACT:}

This work aims to present some reflections from meetings and dialogues developed in the workshop entitled Desbordar developed with users of the mental health service at Casa Verde Day Hospital located in the South Zone of Rio de Janeiro. The text is constructed from a polyphony echoed by the voices of patients and research developed by the authors in the face of perceptions about language, and the proposed method, where the bonds of language, images and words are released from a homogenization that imprison them in a unique and limiting model.

Keywords: Contemporary Embroidery. Art Education. Clinic.

GUIMARÃES, Mariana; SERFATY, Gabriela. Desbordar como contraconduta.

PÓS:Revista do Programa de Pós-graduação em Artes da EBA/UFMG. v.10, n.20: nov.2020

Disponível em < $\underline{\text { https://doi.org/10.35699/2237-5864.2020.20667 }>~}$ 


\section{RESUMEN:}

El objetivo de este trabajo es presentar algunas reflexiones de reuniones y diálogos desarrollados en el taller titulado Desbordar desarrollado con usuarios del servicio de salud mental en el Hospital de Día Casa Verde ubicado en la Zona Sur de Río de Janeiro. El texto se construye a partir de una polifonía reflejada por las voces de los pacientes y la investigación desarrollada por los autores frente a las percepciones sobre el lenguaje, y el método propuesto, donde los lazos del lenguaje, las imágenes y las palabras se liberan de una homogeneización que los encarcela. Un modelo único y limitante.

Palabras clave: Arte. Bordado Contemporáneo. Educación Artística. Clínica

Artigo recebido em: 15/05/2020

Artigo aprovado em: 22/09/2020 


\section{Fio coletivo}

— Por que o meu bordado é sempre na linha?Como eu faço para sair da linha? (R.)

No desejo de construir um texto a partir do encontro entre a clínica e as práticas artísticas, que ampliam os sentidos e potencializam a experiência latente do corpo como testemunha das afecções de outros corpos, convocamos o fio para iniciar nossa escrita. Tensionamos esse fio como ferramenta para fazer vibrar certas estruturas rígidas e expandir a possibilidade de criação como parte do trabalho artístico-clínico. É em virtude desses tensionamentos que o fio se liga a diversos pontos sem se polarizar e, dependendo com quem se conjuga, é capaz tanto de se expandir quanto de se contrair, pois detém a potência da incerteza viva.

O fio tem um percurso próprio. Se esticarmos um fio no espaço em uma direção horizontal, e desenharmos mentalmente uma linha do tempo, podemos historicizá-lo dentro de sua própria materialidade. Do mesmo modo, se traçarmos essa linha na vertical, encontramos uma discussão que conecta o fio às questões ligadas à relação entre céu e terra, humano e divino, mantendo o fio como condutor do entre, rompendo as polaridades. Em uma dinâmica rizomática, nos aproximamos de uma compreensão do fio a partir da lógica das redes e conexões de estruturas descentralizadas. São histórias dentro de histórias, refazendo outras histórias, vestígios de memórias perdidas, uma atualização constante da prática e da linguagem.

Em múltiplos diálogos e encontros, o fio é o dispositivo de mediação, que faz ver e falar, instaura a conexão e a partilha de experiências sensíveis. Nesse sentido, no encontro com o outro, é possível a construção de uma rede de relações e reflexões que nos auxiliam a estruturar o pensamento e a investigação sobre o bordado contemporâneo e as forças que compõem a linguagem. Este trabalho se debruçou sobre a prática do bordado junto a pacientes psiquiátricos portadores de distintos sofrimentos mentais. Um grupo heterogêneo, que a princípio não apresentava nenhuma familiaridade com a técnica, mas que se mostrou interessado em experimentar.

Optamos por trazer recortes e fragmentos de diálogos ${ }^{1}$ presentes nos nossos encontros semanais, ${ }^{2}$ tecendo assim uma trama íntima, carregada em sua dimensão com o desejo da compreensão dos dispositivos, capaz de acessar a memória e recriar com seus vestígios novas formas de lidar consigo

GUIMARÃES, Mariana; SERFATY, Gabriela. Desbordar como contraconduta.

PÓS:Revista do Programa de Pós-graduação em Artes da EBA/UFMG. v.10, n.20: nov.2020

Disponível em < https://doi.org/10.35699/2237-5864.2020.20667> 
mesma. Os diálogos entre o grupo presente em todas as terças-feiras de manhã, na sala principal da casa, apontam caminhos de reflexões para questões políticas com a arte, questões sobre o que seja o artístico, sobre o que é considerado artesanato. Os limites da arte apareciam, e a vontade de fazer desse bordado um produto para ser vendido também surgia como uma possibilidade, além de muitos trabalhos terem sido construídos como ofertas para médicos, terapeutas e familiares dos participantes, como um modo muito prosaico e alegre de afirmar e legitimar o trabalho realizado.

\section{Tecido texto}

No desejo de incorporação do fio como potência de instauração de encontros, faz-se necessário o acesso aos códigos presentes na linguagem têxtil e nas relações que se estabelecem entre o texto e o tecer.

Tecer é enunciar. Todo texto é tecido, assim como todo tecido é texto. $O$ têxtil nos dá uma significação que pode ser interpretada quando se tece, do mesmo modo quando se discorre um texto. Ambos contêm uma elaboração de algo novo, possuem um conteúdo mental, que parte de uma estrutura organizada por repetição e ritmo, que durante o fazer se ordenam e se organizam em uma nova disposição. O ritmo é o que encanta e apavora. Anterior a linguagem, provoca uma espera, suscita um desejar, "o ritmo não é medida, é tempo original. É um ir em direção a algo" (PAZ, 2012, p. 64).

— Eu não gosto de rádio, o rádio deixa a pessoa sozinha, prefiro bordar. O rádio me neurotiza. Eu gosto de fazer coisas criativas. (L. A.)

Cada encontro é permeado por textos que o inspiram, vindos principalmente de livros de poesia, disponibilizados sobre a mesa localizada na sala principal da instituição. $O$ grupo é formado por pacientes de diversas idades e diferentes localidades do Rio de Janeiro. As falas são presentes por meio de músicas, ruídos, vozes, delírios e até gritos. Desde o primeiro dia, optamos por realizar as oficinas na sala da casa, convocando assim todos os pacientes a participarem dos encontros, de modo ativo ou distante. Há aqueles pacientes que se sentam à mesa para de fato bordar, há aqueles que permanecem no sofá, mais distante, e bordam com as palavras, trazendo para a oficina comentários que compõem esse cenário. O que importa é tecer coletivamente, incluindo os atravessamentos presentes nas interrupções, que fazem esse desbordar algo cotidiano.

GUIMARÃES, Mariana; SERFATY, Gabriela. Desbordar como contraconduta.

PÓS:Revista do Programa de Pós-graduação em Artes da EBA/UFMG. v.10, n.20: nov.2020

Disponível em < https://doi.org/10.35699/2237-5864.2020.20667> 
A cada semana, propomos leituras que relacionem o texto com o tecer, mitologias; atualizações de histórias e poesias; catálogos de artistas que trabalham com bordado, como Bispo do Rosário, Rosana Palazyan, Ana Maria Maiolino, Brígida Baltar, etc. Na aposta da repetição, fizemos uma convocação para iniciarmos um exercício de palavras que começassem com a sílaba "te". Iniciamos um dos encontros em meio ao caos inicial. As palavras convocaram todos os presentes a participar: televisão, teleférico, tesoura, tempo, tensão. O exercício convocou o coletivo e instaurou um ritmo, uma presença e, posteriormente, a construção de algumas reflexões sobre as relações entre o texto e o tecer. Nesse instante, decidimos que seria interessante bordar essas palavras ditas de modo espontâneo e coletivo.

— Eu não estou dando conta de ver. Fui à benzedeira e não deu jeito, não dou conta de ver. Não dou conta mesmo de bordar. (F.)

— Palavra não se borda, se fala! (L.)

Assim vieram muitas outras, de todos os lados da sala, surgiam sugestões de palavras que começassem com a mesma sílaba, muitas foram repetidas, e ditas nesta ordem: tecer, texto, terapia, tensão, teatro, termômetro, tecido, teia, tesoura, tear, textura, televisão, tempo, tessitura, tecnologia, tempo, tempo, tempo, tempo, tecnologia, tentativa, Teresópolis, Teresina, Tereza, termostático, Terezinha, temperatura, testar, teste, tele-sena, Tele-Rio, telhado, telefone, temos, terror, tédio, telegrama, telefonema, tempero, terno, temperado, tenente, tesouro, teco-teco, telha, teleférico, tesão, templo, tempestade, teimosia, ternura, telúrica, Tebas, Teseu, teto, testamento, teto, testemunho, telégrafo, tênis, tema, teorema, teoria, tenra, terra, terrestre, terráqueo, terraço, terreno, terremoto, tédio, telúrica, tetra, teto, telhado, terminal, tensionamento, tempestade, temor, ternura, terna, testa, tédio, teimosia, testosterona, tédio, texto.

GUIMARÃES, Mariana; SERFATY, Gabriela. Desbordar como contraconduta.

PÓS:Revista do Programa de Pós-graduação em Artes da EBA/UFMG. v.10, n.20: nov.2020

Disponível em < $\underline{\text { https://doi.org/10.35699/2237-5864.2020.20667 }>~}$ 
a)

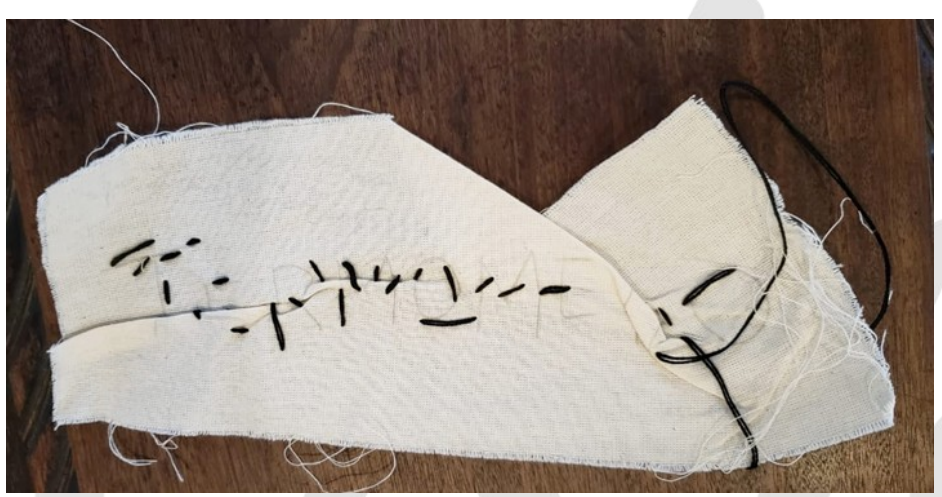

b)

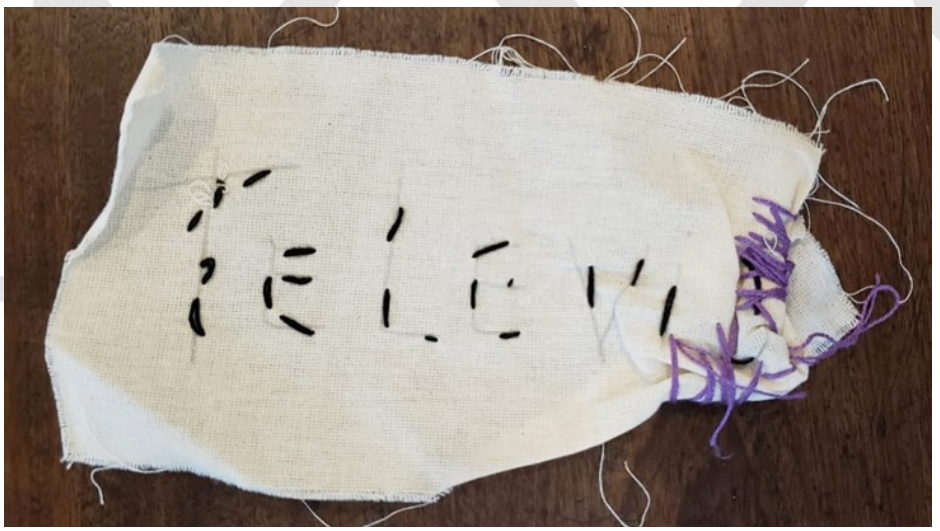

c)

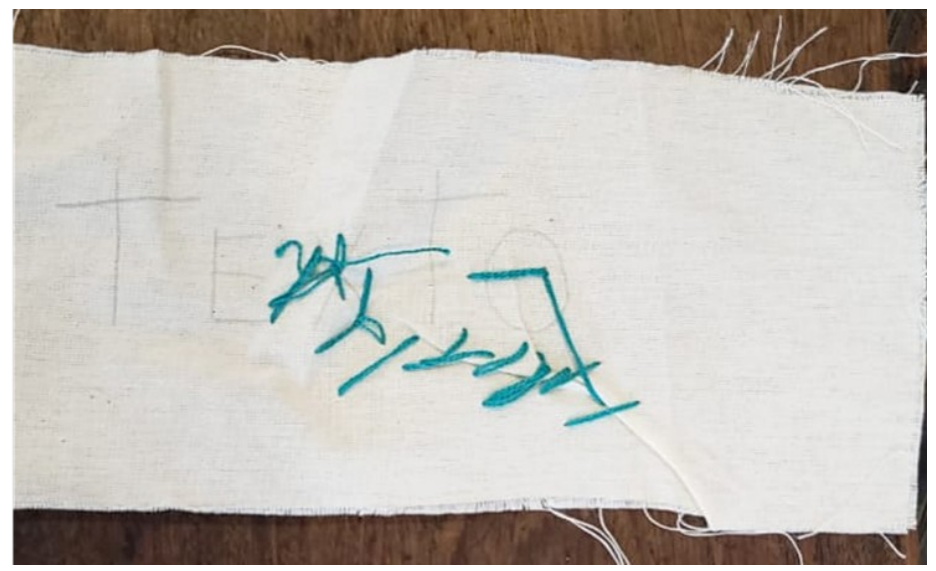

Fig. 1 - Palavras bordadas pelos pacientes

Fonte: Acervo das autoras.

Foto: Jayme Preste P. Neto.

GUIMARÃES, Mariana; SERFATY, Gabriela. Desbordar como contraconduta.

PÓS:Revista do Programa de Pós-graduação em Artes da EBA/UFMG. v.10, n.20: nov.2020

Disponível em < https://doi.org/10.35699/2237-5864.2020.20667> 


\section{Desvio como potência}

A linguagem se constrói entre fios visíveis ou não e tem uma lógica na experiência individual e coletiva, simultaneamente. Compreender a linguagem a partir de uma nova percepção nos permite cartografar as relações e traçar uma estética-ética, que é definida por suas conexões e entrecruzamentos.

Trabalhar com pacientes usuários do serviço de saúde mental é justamente o que nos impulsiona a pensar o que transborda dessa experiência, sobretudo o que foge a uma normatividade. O esquizo ${ }^{3}$, aquele que produz suas linhas desviantes, nos ensina que o bordar está para além de seguir pontos com linhas, está no gesto, que se faz quando um paciente, ao pegar o fio para bordar uma palavra, transforma a palavra em um fio.

— Não existe arte dos loucos, nem loucura artística. Existe arte, e isso é o que basta. Eu sou até artista, mas não dou conta da criação. Eu não entrava no seu assunto, mas o Bispo, ele me ajudou a introduzir no seu assunto. Agora estou introduzindo no seu assunto. (F.)

A pesquisa com o bordado na arte contemporânea brasileira é inaugurada com a pesquisa sobre o trabalho de Arthur Bispo do Rosário. Negro, nordestino, pobre, louco, habitante de um cárcere psiquiátrico. Bispo é resistência. Bispo é origem, é o todo já começado da linguagem. Recria e desloca a linguagem têxtil. Abre caminhos para a descolonização de práticas arraigadas em opressão e violência. Inaugura o convívio acadêmico com as práticas da casa, menores, invisíveis e feita por mulheres. Bispo desloca, altera, expande os sentidos. Bispo está conosco em cada momento dos encontros, convocado por alguns dos participantes como identificação máxima de uma arte realizada por esquizofrênicos.

No ano de 1989, a obra de Arthur Bispo do Rosário foi apresentada ao grande público na exposição póstuma do artista, falecido nesse mesmo ano. Intitulada Registros de minha passagem pela terra, com curadoria de Frederico Moraes, foi realizada no Parque Lage, Rio de Janeiro, e influenciou muitos artistas e pesquisadores.

GUIMARÃES, Mariana; SERFATY, Gabriela. Desbordar como contraconduta.

PÓS:Revista do Programa de Pós-graduação em Artes da EBA/UFMG. v.10, n.20: nov.2020

Disponível em < https://doi.org/10.35699/2237-5864.2020.20667> 
Também no ano de 1989, o artista cearense José Leonilson iniciava seus trabalhos de bordado e costura, tornando-se um dos principais e primeiros expoentes da atualização da linguagem do bordado e da costura na arte contemporânea brasileira. O artista é conhecido por sua obra singular e autobiográfica, composta por inúmeros bordados que apresentam parte de sua intimidade, como um diário que narra a relação sensível do artista com o mundo, revelando o quanto o pessoal é político no conjunto de sua obra.

São dois homens que apontam para a renovação da linguagem e para a incorporação da práxis na pesquisa em arte contemporânea. Trabalho originariamente restrito ao espaço doméstico e designado às mulheres. É na arte contemporânea, entretanto, que os estereótipos de gênero são dissolvidos.

Do mesmo modo, a história do bordado e dos trabalhos com linha e agulha traz consigo uma memória de padronização violenta do corpo feminino - de docilidade e de obediência -, cujas práticas de trabalho, como entendemos, carregam uma carga histórica de opressão e violência, de colonização e domesticação do pensamento e práxis femininas. O corpo feminino forjado ao trabalho doméstico tem origem em um projeto político e econômico ligado a um estilo de vida, a uma moral e ética relacionadas à existência de um homem, proprietário de terras, bens, de um oikos, que seria um conjunto de bens geridos pelo seu proprietário e que continha em sua composição a família e os escravizados, também como propriedade.

Muitas aprendizagens e habitus estavam presentes no fortalecimento desse corpo dócil. O bordado e muitos outros trabalhos manuais estiveram a serviço de um sistema que oprimia corpos, disfarçado de delicadeza e feminilidade.

O bordado cujo nome é livre é, na verdade, preso a uma quantidade enorme de regras, de dicionários de pontos, de formas e modos. Bordado é representação gráfica. Bordar é desenhar com a linha, é organização de pensamento, de caminhos. Bordar é traçar. Movimento incessante de agir. Nesse sentido, a partir do trabalho dos artistas Arthur Bispo do Rosário e José Leonilson, apostamos em uma linguagem do bordado menos domesticada, cuja força de desvio, daquilo que desalinha, é o que mais nos interessa.

GUIMARÃES, Mariana; SERFATY, Gabriela. Desbordar como contraconduta.

PÓS:Revista do Programa de Pós-graduação em Artes da EBA/UFMG. v.10, n.20: nov.2020

Disponível em < https://doi.org/10.35699/2237-5864.2020.20667> 
a)

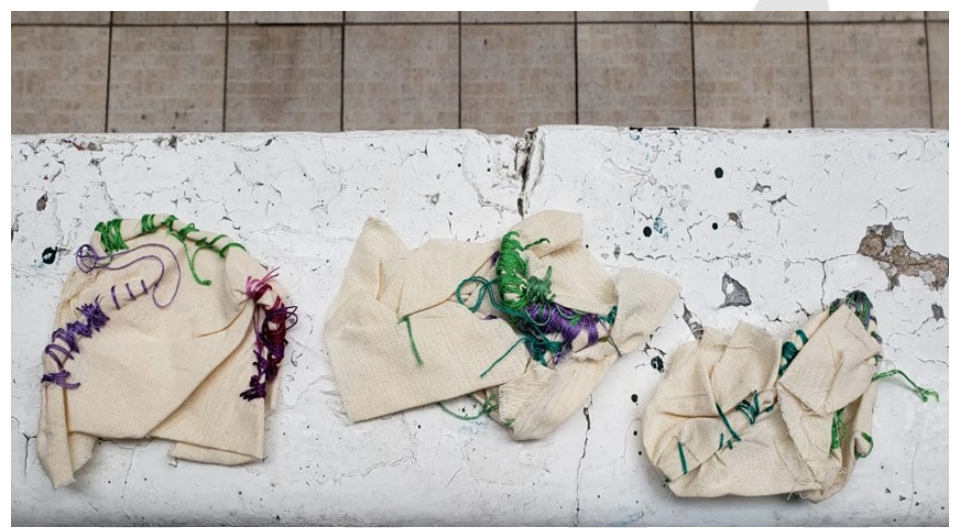

b)

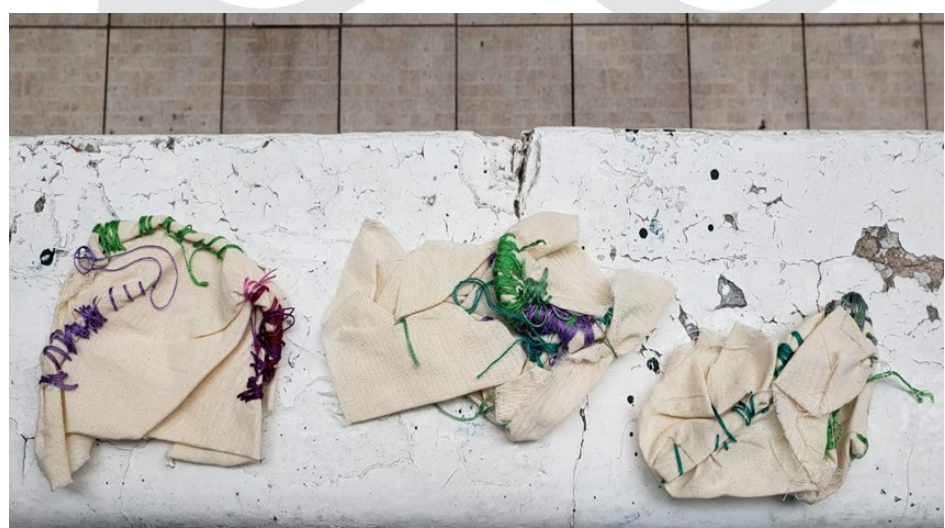

Fig. 2 - Série de bordados desenvolvidos por uma participante do grupo Fonte: Acervo das autoras.

Foto: Jayme Preste P. Neto.

O que apresentamos como método de trabalho é um dispositivo, é deixar aparecer o definido, a princípio, como um erro. Apostamos no desalinhar e no desbordar como um contra método, encontro da primazia da clínica e da arte, que juntas ajudam a sustentar o inacabado como uma forma de estética. Em perspectiva de desvio, diferir, diferenciar são sentidos dados à clínica, está na sua raiz etimológica, que deriva do termo latino clinamen, 'desvio'. De modo que, por meio de trajetos desviantes, surge um inventário de modos de existência anulados e adaptados a uma certa norma. Apostamos nesta clínica que afirma as subjetividades desviantes como o louco e o artista como os vaga-lumes que apontam brechas possíveis diante dos padrões opressores de normalidade. Surge desse encontro da loucura com a arte; uma narrativa ético-poética-política que aponta para a reinvenção de um novo território, que ultrapasse a dicotomia historicamente construída nas relações entre loucura e sociedade.

GUIMARÃES, Mariana; SERFATY, Gabriela. Desbordar como contraconduta.

PÓS:Revista do Programa de Pós-graduação em Artes da EBA/UFMG. v.10, n.20: nov.2020

Disponível em < $\underline{\text { https://doi.org/10.35699/2237-5864.2020.20667 }>~}$ 
- Meu bordado é um elefante, o nome dele é Tomi. Não tem história, não tem forma. Só tem nome. (S.)

\section{Descolonizar práticas}

A descolonização da linguagem, nesse sentido, está intimamente relacionada à promoção de ações e práticas descolonizadoras, que busca estratégias de inverter a relação com a produção de conhecimento e de aprendizagem. Um aprender cotidiano, construído a partir de nossos próprios pensamentos, que busque a coerência entre pensar, agir, e que possa problematizar a partir da experiência vivida, atualizando a memória, os gestos, unindo os sentidos do corpo e mente.

Entendendo, nessa experiência com a loucura, que o lugar do sujeito e do objeto se misturam, o lugar do saber-poder se desfaz, o que aparece é uma relação de acompanhamento, que se faz no desbordar, sem que haja uma relação de verticalidade. A clínica e a arte se casam quando ambas deixam aparecer o que parece inacabado e torto para alguns.

— Dá um nó, por favor. (V.)

— Bordado não tem certo e errado, né? (S.)

—É muito veloz o bordado. (L.)

— Eu não era capaz de construir nada, estou fazendo uma coisa que toda minha vida eu queria fazer. (F. S.)

— Tô fazendo uma pipa e tem que tomar cuidado. (F.)

— Eu tô evitando causar problemas para as pessoas. (L.A)

Nessa direção, o que propomos como destecer seria uma prática e conduta descolonizadora frente à linguagem tradicional têxtil, subjugada ao espaço doméstico como coisa de mulher. Destecer estaria relacionado a fazer coexistir, no interior da mesma linguagem, práticas antagônicas, revelando as tensões sociais, históricas e plásticas presentes na linguagem têxtil e criando uma outra

GUIMARÃES, Mariana; SERFATY, Gabriela. Desbordar como contraconduta.

PÓS:Revista do Programa de Pós-graduação em Artes da EBA/UFMG. v.10, n.20: nov.2020

Disponível em < https://doi.org/10.35699/2237-5864.2020.20667> 
linguagem. Destecer como método na produção de novas narrativas e processos de subjetivação possibilita novos modos de existência. A relação estabelecida livremente com a linguagem produz a possibilidade de aprendê-la e de reinventá-la.

Trata-se de criar uma dobra, uma fissura nos processos que sejam "capazes de resistir ao poder, bem como se furtar ao saber, mesmo se o saber tenta penetrá-los e o poder tenta apropriar-se deles", assim como afirma Deleuze (1992, p. 116) ao analisar a obra de Michel Foucault e dos modos de subjetivação do ser humano. A dobra possibilitada pelo destecer como contraconduta revela um território e seu processo de construção, faz coexistir um dentro e um fora simultaneamente, possibilitando assim a invenção de um território outro, onde é possível fazer convergir outras forças.

Ao apostar em uma subjetividade feita de dobras do mundo, estamos dizendo que não se trata de algo individual, privado e independente dos múltiplos atravessamentos - o fora está dentro, sendo a subjetividade uma inflexão produzida por fluxos de passagem.

O conceito de dobra, evocado por Foucault, tal como Deleuze o interpreta, pode nos servir como operador ao nos mostrar que diferentes formas de adoecimento, ao longo da história, seriam distintas dobras do mundo. Desse modo, o adoecimento talvez pudesse escapar da equação de sujeição, má consciência e ressentimento. Assim é que cada corpo produz suas espessuras até se duplicar e criar uma espécie de forro, como dissemos. É isso que nos dá a impressão de que o sofrimento é uma experiência solitária e que, portanto, pertence apenas ao universo particular, quando, na verdade, há muitos mundos povoando aquele corpo povoado de afetos e intensidades.

$\mathrm{Na}$ instauração de novas proposições e métodos com a técnica, outras nomeações e caminhos surgem frente à linguagem, mas sobretudo frente à existência.

— Tranquilidade, nem tanta tranquilidade assim, concentração, ou não? É outra coisa, é um não sei o quê... o bordado me traz um não sei o quê... bordado requer tranquilidade. Tranquilidade é verbo? Não é substantivo, é comum então... (J.)

GUIMARÃES, Mariana; SERFATY, Gabriela. Desbordar como contraconduta.

PÓS:Revista do Programa de Pós-graduação em Artes da EBA/UFMG. v.10, n.20: nov.2020 Disponível em < https://doi.org/10.35699/2237-5864.2020.20667> 
Nesse sentido, o destecer é político, pois nos permite acesso aos processos e formas de opressão vividos e nos liberta deles. O desfazimento nos autoriza a dissolver uma forma fixada e construída, ao mesmo tempo que revela uma nova forma que se apresenta a partir da desconstrução da forma anterior. O destecer está além da linguagem, embora só possa ser acessado a partir do encontro com a linguagem. Seria uma expansão da linguagem para novos usos e significados. O destecer nos apresenta novos sentidos e, sobretudo, a possibilidade de nos libertar dos sistemas de dominação e homogeneização existentes nas artes visuais, na educação e na clínica. Além disso, amplia as possibilidades de criação, reinvenção, libera as padronizações e o resultado, que é o próprio processo em si, mostra-se mais plural e, de algum modo, mais caótico. Permite-nos escapar da violência binária, existente nas instituições e nas linguagens - não há certo nem errado, avesso ou direito, casa e rua, masculino e feminino, louco nem são -, tem-se a apreensão do ritmo e da duração, do movimento originário que está por trás de toda criação que contém a liberdade. Interessa-nos o movimento.

— Eu vou embora no bordado, abre caminhos. Tira os pensamentos ruins. (R.)

— Bordado abre caminhos e traz felicidade. É um bom negócio. (L. A.)

— Estou fazendo umas trilhas para chegar no caminho certo. (F. B.)

— Eu não ando em trilha, tenho medo de cobras. (L.)

O fio só produz sentido ao compreendermos o todo por trás de sua materialidade, o movimento incessante do gesto. Apreendendo o movimento do fio, tem-se a consciência do que o fio revela. Nesse sentido, a relação que estabelecemos com a linguagem em nossos encontros é fazer o próprio ponto de vista do movimento que ela produz, entrando e desvelando suas forças, ritmos e duração. Seguir a linguagem é lançar-se ao devir que ela convoca. A forma só existe enquanto força, o fio só existe enquanto movimento, enquanto repetição.

É na repetição que se produz o ritmo, que organiza e codifica um determinado meio. É preciso encontrar o Si da Repetição, a singularidade naquilo que se repete, pois não há repetição sem um repetidor, nada de repetido sem alma repetidora. $\mathrm{A}$ primeira repetição é a repetição do Mesmo, que se explica pela identidade do conceito ou da representação: a segunda é a que compreende a si mesma na alteridade da Ideia, na heterogeneidade de uma "apresentação" (DELEUZE, 2018, p. 44).

GUIMARÃES, Mariana; SERFATY, Gabriela. Desbordar como contraconduta.

PÓS:Revista do Programa de Pós-graduação em Artes da EBA/UFMG. v.10, n.20: nov.2020

Disponível em < $\underline{\text { https://doi.org/10.35699/2237-5864.2020.20667 }>~}$ 
O interior da repetição seria sempre afetado por uma ordem da diferença. Nessa observação da diferença na repetição, produzimos um processo de diferenciação dentro da repetição que produz processos de expansão, liberdade e, nesse sentido, todos saímos ganhando, artistas, terapeutas, pacientes, educandos. Estreitamos fronteiras, produzimos heterogeneidades e, por fim, "piscamos juntos".

— Nós somos vaga-lumes isolados, mas estamos piscando, eu li no seu livro. (P.)

A comunidade dos vaga-lumes vive do contraste, e só aparece quando uma delicada luz é capaz de dançar na escuridão. Nos momentos em que os holofotes espetacularizam a vida, poucos são os vaga-lumes que sobrevivem, quase não podemos vê-los. Isto se intensifica quando o raio inquisidor dos projetores penetra a visão, tornando-a vidrada, e perdemos a capacidade de olhar. Assim, é preciso criar condições favoráveis para que eles possam sobreviver e meios possíveis para vê-los. Caso contrário,

um vaga-lume acaba por desaparecer da nossa vista e ir para um lugar onde será, talvez, percebido por outra pessoa, lá onde sua sobrevivência poderá ser observada ainda (...) Feito o sol que desaparece de nossas vistas, mas, nem por isso, deixa de estar em outro lugar no oriente (DIDI-HUBERMAN, 2011, p. 55).

Uma sobrevivência, apesar de tudo, é algo que se revela capaz de transpor o horizonte das construções totalitárias. O vaga-lume tenta escapar da cegueira emitida pelo excesso de luz dos holofotes. Esses vaga-lumes soltam lampejos de luz como "corpos luminosos passageiros na noite. Bolas de fogo que atravessam o horizonte, cometas que aparecem e vão se perder mais adiante" (DIDIHUBERMAN, 2011, p. 144)

Viver, apesar de tudo, é uma aposta. Uma resistência que surge quando os vaga-lumes resolvem criar uma comunidade capaz de sobreviver ao abismo e a tudo aquilo que impede sua existência, fazendo fazer valer uma força a favor da vida, uma força que lampeja. Assim, é possível pensar em gestos-vaga-lumes, movimentos-vaga-lumes, um certo devir vaga-lume, que se expressa de diversos modos - em que o desejo de existir vence qualquer tentativa de aniquilamento da vida: uma bola de fogo que atravessa o horizonte.

GUIMARÃES, Mariana; SERFATY, Gabriela. Desbordar como contraconduta.

PÓS:Revista do Programa de Pós-graduação em Artes da EBA/UFMG. v.10, n.20: nov.2020

Disponível em < $\underline{\text { https://doi.org/10.35699/2237-5864.2020.20667> }}$ 
A força do destecer acontece onde só parece haver um corpo adoecido e esvaziado de sua vitalidade, e revela que, entre normal e patológico, há saúdes por vir, há mundos por vir. A aposta dessa escrita é em direção a esta saúde, para deixar que o sofrimento germine outras possibilidades de existência.

a)

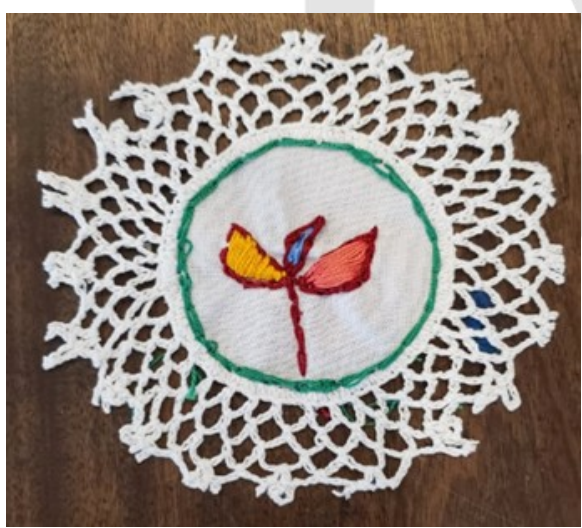

b)

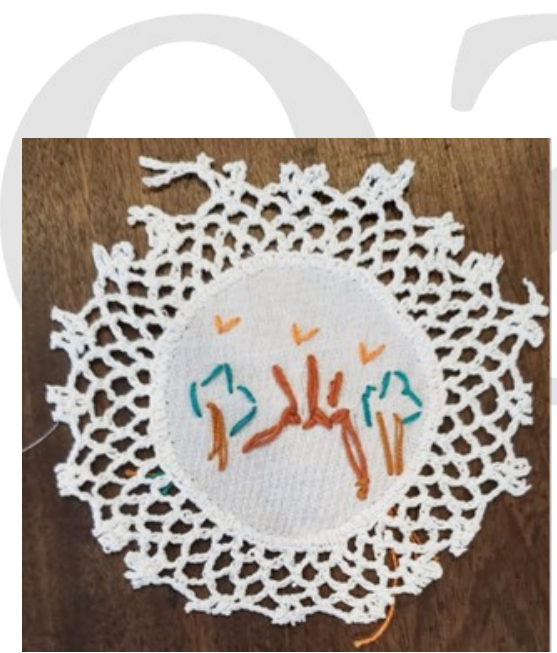

Fig. 3 - Bordados da série "Flores", realizado por participante da oficina Fonte: Acervo das autoras.

Foto: Jayme Preste P. Neto.

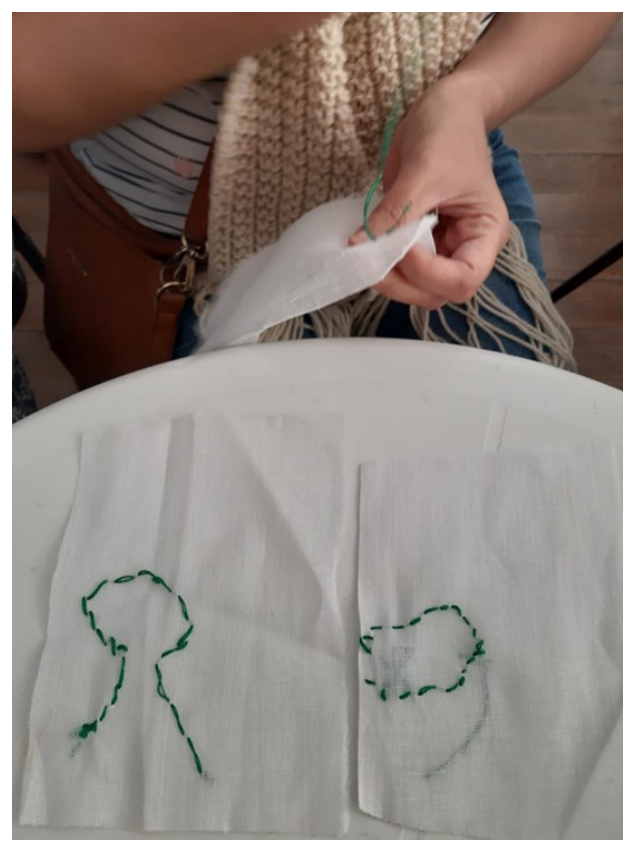

Fig. 4 - Árvores. Detalhe de série bordada por participante dos encontros Fonte: Acervo das autoras.

Foto: Jayme Preste P. Neto.

GUIMARÃES, Mariana; SERFATY, Gabriela. Desbordar como contraconduta.

PÓS:Revista do Programa de Pós-graduação em Artes da EBA/UFMG. v.10, n.20: nov.2020 Disponível em < https://doi.org/10.35699/2237-5864.2020.20667> 


\section{REFERÊNCIAS}

DELEUZE, Gilles. Diferença e repetição. Rio de Janeiro: Paz e Terra, 2018.

DELEUZE, Gilles. Conversações. São Paulo: Editora 34,1992.

DIDI-HUBERMAN, Georges. Sobrevivência dos vaga-lumes. Belo Horizonte: Editora UFMG, 2011.

PAZ, Octavio. O arco e a Lira. São Paulo: Cosac Naify, 2012.

GUIMARÃES, Mariana; SERFATY, Gabriela. Desbordar como contraconduta.

PÓS:Revista do Programa de Pós-graduação em Artes da EBA/UFMG. v.10, n.20: nov.2020

Disponível em < https://doi.org/10.35699/2237-5864.2020.20667> 


\section{NOTAS}

1 Os depoimentos e diálogos foram cedidos livremente pelos participantes das oficinas. Optamos por preservar suas identidades, referindo a eles apenas com a inicial do primeiro nome.

2 Os encontros das oficinas do Desbordar acontecem todas as terças-feiras pela manhã, desde setembro de 2018. Além das mediadoras das oficinas, os encontros contam com a presença de uma equipe multidisciplinar de profissionais da área da saúde, como enfermeiras, terapeutas, médicos e diversos estagiários. A Instituição e os profissionais envolvidos propõem distintas atividades artísticas para os pacientes, além de um cronograma rico em apresentações, debates, mostra, saraus, etc., valorizando, dessa forma, a expressão e singularidade de cada um e suas distintas potencialidades. Cabe ressaltar que a realização dos encontros ocorreu a partir de um convite de Gabriela Serfaty, artista, pesquisadora, terapeuta e psiquiatra, que trabalha e acompanha os pacientes na Casa Verde, a Mariana Guimarães, artista, pesquisadora e educadora, que desenvolve uma pesquisa extensa sobre o fio na arte contemporânea, em diálogos com a arte popular, educação e clínica há aproximadamente 20 anos.

3 Existe uma intenção em usar a palavra esquizo, que vai além do termo de diagnóstico esquizofrênico. Esquizo como potência esquizo, que rompe a normalidade, as estruturas rígidas de representação, e busca fugir da conotação adoecido e devolve a esse modo operante de subjetividade sua potência. $O$ termo deriva da esquizoanálise. 